\title{
Profil Berpikir Kritis Matematis Mahasiswa dalam Menyelesaikan Soal Trigonometri Ditinjau dari Tingkat Kepercayaan Diri
}

\author{
Bagus Dwi Wicaksono ${ }^{*}$ dan Erlina Prihatnani ${ }^{2}$ \\ Program Studi Pendidikan Matematika, Universitas Kristen Satya Wacana \\ Jl. Diponegoro No. 52-60 Sidorejo, Salatiga, Jawa Tengah, Indonesia \\ 1*202015005@student.uksw.edu \\ 2erlina.prihatnani@gmail.com
}

Artikel diterima: 14-11-2018, direvisi: 24-01-2019, diterbitkan: 31-01-2019

\begin{abstract}
Abstrak
Memasuki era Masyarakat Ekonomi Asean (MEA) diperlukan calon guru yang berkualitas agar mampu menyiapkan generasi yang dapat bersaing secara global. Salah satu kemampuan yang harus dimiliki seorang calon guru adalah kemampuan berpikir kritis matematis. Sebuah penelitian menyimpulkan bahwa kemampuan berpikir kritis dipengaruhi oleh kepercayaan diri. Penelitian ini bertujuan untuk mendeskripsikan kemampuan berpikir kritis matematis mahasiswa Pendidikan Metematika FKIP UKSW ditinjau dari tingkat kepercayaan diri. Jenis penelitian ini adalah deskriptif kualitatif. Subjek penelitian merupakan mahasiswa Pendidikan Matematika FKIP UKSW yang diambil berdasarkan 2 kategori yaitu mahasiswa dengan kepercayaan diri tinggi atau S1 dan mahasiswadengan kepercayaan diri rendah atau S2. Hasil penelitian ini menunjukkan bahwa terdapat perbedaan kemampuan berpikir kritis matematis antara subjek S1 dan subjek S2 dimana subjek S1 memenuhi semua aspek FRISCO (fokus, reason, inference, situasion, clarity, dan overview) sedangkan subjek S2 hanya memenuhi aspek focus, reason, inferencedanclarity.

Kata kunci: calon guru, kemampuan berpikir kritis, kepercayaan diri.

\section{Profil of Student's Mathematical Critical Thinking in Solving Trigonometry Question Viewed from Self-Confidence}

Abstract

Entering the era of the Asean Economic Community (MEA) requires qualified teacher candidates to be able to prepare generations that can compete globally. One of the abilities that a prospective teacher must possess is mathematical critical thinking skills. A study concluded that critical thinking skills are influenced by self-confidence. This study aims to describe the mathematical critical thinking skills of the SWCU FKIP Mathematics Education students in terms of their level of confidence. This type of research is qualitative descriptive. The research subjects were SWCU FKIP Mathematics Education students taken based on 2 categories, namely students with high self-confidence or S1 and students with low self-confidence or S2. The results of this study indicate that there are differences in mathematical critical thinking skills between S1 subjects and S2 subjects where S1 subjects fulfill all aspects of FRISCO (focus, reason, inference, situation, clarity, and overview) while 52 subjects only fulfill focus, reason, inference, and clarity aspects.

Keyword: prospective teacher, critical thinking, self-confidence.
\end{abstract}




\section{Pendahuluan}

Memasuki era Masyarakat Ekonomi Asean (MEA) maka diperlukan sumber daya manusia (SDM) yang berkualitas. Upaya yang dapat dilakukan untuk meningkatkan kualitas SDM adalah dengan menyiapkan calon guru yang berkualitas dimana kemampuan yang harus dimiliki calon guru yang berkualitas adalah kemampuan berpikir tingkat tinggi. Menurut Heong dkk.,(2011), berpikir tingkat tinggi adalah kemampuan seseorang dalam menerapkan informasi baru atau pengetahuan sebelumnya dan memanipulasi informasi untuk mendapatkan jawaban yang mungkin dalam situasi yang baru. King, Ludwika, \& Rohani(1998) menyatakan, "Higher order thinking skills include critical, logical, reflective, metacognitive, and creative thinking". Hal ini menunjukkan bahwa berpikir kritis merupakan salah satu kemampuan berpikir tingkat tinggi.

Kemampuan yang penting untuk dimiliki calon guru termasuk didalamnya mahasiswa pendidikan matematika adalah kemampuan berpikir kritis matematis. Sejalan dengan hal ini, Santoso (2016) menyatakan bahwa sebagai calon guru, mahasiswa pendidikan matematika harus memiliki kemampuan berpikir logis, analitis, sistematis, kritis, dan kreatif. Menurut Gunawan (2013) berpikir kritis adalah kemampuan untuk melakukan analisis, menciptakan dan menggunakan kriteria secara objektif, dan melakukan evaluasi data. Adapun berpikir kritis menurutRazak (2017) adalah kemampuan untuk mengevaluasi secara sistematis bobot pendapat pribadi dan pendapat orang lain . Lebih lanjut, Alexandra \& Ratu (2018) menyatakan bahwa kemampuan berpikir kritis matematis adalah kemampuan memecahkan masalah, menganalisis, mengevaluasi, membandingkan sesuatu dengan alasan yang baik, agar dapat mengambil keputusan yang terbaik dalam memecahkan masalah matematika. Jika calon guru memiliki kemampuan berpikir kritis matematis yang baik maka diharapkan guru dapat menyelenggarakan pembelajaran yang berkualitas sehingga dapat melatih kemampuan berpikir kritis siswa.

Ennis (1996) mengemukakan bahwa seseorang yang memiliki kemampuan berpikir kritis idealnya memiliki beberapa aspek yang biasa disingkat FRISCO (focus, reason, inference, situation, clarity, overview), yaitu sebagai berikut: 1) focus: menentukan hal yang menjadi fokus dalam permasalahan tersebut; 2) reason: mengetahui alasan-alasan yang mendukung atau melawan putusanputusan yang dibuat berdasarkan situasi dan fakta yang relevan; 3) inference: membuat kesimpulan yang beralasan dan dapat dipertanggungjawabkan; 4) situation: menerapkan konsep pengetahuan yang dimiliki sebelumnya untuk menyelesaikan masalah pada situasi yang lain; 5) clarity: menjelaskan arti atau istilah-istilah yang digunakan; 6) overview: melakukan pengecekan atau pemeriksaan kembali terhadap langkah penyelesaian masalah. Menurut Mahardiningrum \& Ratu (2018), keenam aspek tersebut saling berkaitan dan bukan merupakan serangkaian langkah, tetapi lebih kepada daftaran yang digunakan untuk memastikan bahwa kita telah melakukan hal-hal yang sama. 
Terdapat beberapa penelitian yang telah meneliti kemampuan berpikir kritis mahasiswa pendidikan matematika. Misalnya, Paradesa (2015) yang menyimpulkan bahwa secara umum tingkat kemampuan berpikir kritis matematis mahasiswa melalui pendekatan konstruktivisme pada mata kuliah matematika keuangan dikategorikan kurang. Indikator yang sering muncul hanya kemampuan menggeneralisasi sedangkan kemampuan mengidentifikasi, merumuskan masalah kemodel matematika, mendeduksi dengan menggunakan prinsip, dan memberi penjelasan lanjut jarang muncul atau dapat diartikan bahwa kemampuan mahasiswa pada indikator tersebut masih kurang. Adapun hasil penelitian yang dilakukan oleh Zetriuslita, Ariawan, \& Nufus (2016) menyimpulkan bahwa mahasiswa baik secara keseluruhan maupun berdasarkan level kemampuan matematis (tinggi, sedang, rendah), sudah memiliki kemampuan menggeneralisasi, namun belum memiliki kemampuan untuk mengidentifikasi dan menjastifikasi konsep serta belum memiliki kemampuan menganalisis atau mengevaluasi sebuah algoritma.

Kedua penelitian tersebut telah menunjukkan bahwa kemampuan berpikir kritis mahasiswa berbeda-beda. Berdasarkan hal tersebut muncul rasa ingin tahu bagaimana dengan kemampuan berpikir kritis yang dimiliki mahasiswa pendidikan matematika UKSW. Di Universitas ini berpikir kritis masuk kedalam salah satu misi yang hendak dicapai. Aspek berpikir kritis ini muncul pada misi yang ketiga yaitu mendorong dan mengembangkan sikap serta pemikiran yang kritis. Hal ini berarti kemampuan berpikir kritis menjadi salah satu kemampuan yang diharapkan untuk dimiliki seluruh akademisi dari UKSW termasuk mahasiswa pendidikan matematika.

Hasil observasi yang dilakukan menunjukkan bahwa terdapat mahasiswa pendidikan maematika yang jika diberi soal rutin dengan tingkat kesulitan tinggi masih dapat mengerjakan soal tersebut, tetapi jika diberi soal non-rutin tidak semua mahasiswa dapat mengerjakan dengan benar. Hal ini mengindikasikan bahwa tidak semua mahasiswa pendidikan matematika telah memiliki kemampuan berpikir kritis matematis sesuai dengan yang diharapkan.

Salah satu faktor yang dapat mempengaruhi kemampuan berpikir kritis matematis bagi mahasiswa adalah kepercayaan diri. Penelitian Tresnawati, Hidayat, \& Rohaeti (2017) menyimpulkan bahwa persentase kemampuan berpikir kritis matematis seseorang dipengaruhi oleh kepercayaan diri sebesar 74,6\% sedangkan 25,4\% dipengaruhi oleh faktor lain di luar kepercayaan diri. Persentase tersebut menunjukkan bahwa pengaruh kepercayaan diri pada kemampuan berpikir kritis matematis seseorang masuk ke dalam kategori sangat besar.

Lauster (dalam Fasikhah, 1994) mengemukakan bahwa kepercayaan diri merupakan suatu sikap atau perasaan yakin atas kemampuan diri sendiri sehingga orang yang bersangkutan tidak terlalu cemas dalam tindakan-tindakannya, dapat merasa bebas untuk melakukan hal-hal yang disukai, dan bertanggug jawab atas tindakannya, hangat dan sopan dalam berinteraksi dengan orang lain, dapat 
menerima dan menghargai orang lain, memiliki dorongan untuk berprestasi serta mengenal kelebihan dan kekurangan dirinya. Hal yang sama juga dikemukakan oleh Bandura (dalam Hendriana, 2014) yang menyatakan bahwa kepercayaan diri adalah rasa percaya terhadap kemampuan diri dalam menyatukan dan menggerakkan (memobilisasi) motivasi dan semua sumber daya yang dibutuhkan, dan memunculkannya dalam tindakan yang sesuai dengan apa yang harus diselesaikan, sesuai tuntutan tugas.

Arti penting berpikir kritis bagi calon pendidik matematika dan adanya teori yang menyatakan bahwa kepercayaan diri merupakan salah satu faktor yang dapat mempengaruhi kemampuan berpikir kritis menjadi dasar dilakukannya penelitian untuk mengetahui kemampuan berpikir kritis mahasiswa ditinjau dari kepercayaan diri. Beberapa cara dapat dilakukan untuk mengukur kemampuan berpikir kritis matematis mahasiswa. Hendriana, Rohaeti, \& Sumarmo (2017) menyatakan bahwa berpikir kritis tergolong kemampuan berpikir tingkat tinggi (Higher Order Thinking Skills/HOTS). Sejalan dengan pernyataan tersebut, untuk mengukur kemampuan berpikir kritis bisa menggunakan soal-soal HOTS yang pada umumnya mengukur kemampuan pada ranah C4 hingga C6 (Depdikbud, 2017). Oleh karena itu, dalam penelitian ini akan menggunakan soal dengan kriteria tersebut yaitu soal-soal pada materi trigonometri yang dapat mengukur kemampuan pada ranah C4 hingga C6. Pemilihan materi trigonometri dikarenakan materi tersebut merupakan salah satu matakuliah dasar dalam program studi pendidikan matematika UKSW.

Berdasarkan uraian tersebut, penelitian ini akan menggunakan soal HOTS untuk mengukur kemampuan berpikir kritis matematis mahasiswa. Subjek yang dipilih adalah mahasiswa pendidikan matematika UKSW angkatan 2017 yang sudah mendapat matakuliah trigonometri. Diharapkan penelitian ini dapat memberikan informasi kepada program studi pendidikan matematika UKSW mengenai kemampuan berpikir kritis dari mahasiswa baru. Selain itu, diharapkan informasi ini juga dapat dijadikan dasar kebijakan terkait penyusunan program untuk mencapai misi ketiga.

\section{Metode}

Jenis penelitian ini adalah penelitian kualitatif dangan pendekatan deskriptif. Penelitian ini dilakukan di UKSW pada semester 1 tahun ajaran 2018/2019. Subjek pada penelitian ini adalah 2 mahasiswa pendidikan matematika angkatan 2017 yang mewakili kategori mahasiswa dengan tingkat kepercayaan diri tinggi dan mahasiswa dengan tingkat kepercayaan diri rendah. Penggolongan tingkat kepercayaan diri mahasiswa ditentukan menggunakan angket kepercayaan diri yang diadaptasi dari angket Hendriana dkk., (2017). Angket tersebut disebar kedalam populasi mahasiswa Pendidikan Matematika UKSW angkatan 2017 yang berjumlah 66 orang.

Instrumen dalam penelitian ini adalah peneliti sebagai instrumen utama dan instrumen pendukung berupa soal tes kemampuan berpikir kritis, angket kepercayaan diri, dan pedoman wawancara. Soal tes kemampuan berpikir 
kritis yang digunakan berbentuk uraian dimana pada soal tes tersebut dapat mendeskripsikan indikator berpikir kritis FRISCO (focus, reason, inference, situation, clarity, overview). Setelah diberikan tes, dilakukan wawancara kepada subjek sebagai uji keabsahan data, selanjutnya setelah memperoleh data-data yang diperlukan kemudian dilakukan analisis. Analisis data pada penelitian ini menggunakan model Miles dan Huberman dengan tahapannya yaitu reduksi data, penyajian data, dan penarikan kesimpulan.

\section{Hasil dan Pembahasan}

Subjek dengan kepercayaan diri tinggi diberi kode S1 sedangkan subjek dengan kepercayaan diri rendah diberi kode S2. Berikut soal tes berpikir kritis yang digunakan dalam penelitian ini.

a. Dengan membuat sketsa grafik, tentukan berapa saja nilai $x$ yang memenuhi persamaan $\sin (2 x-$ $30)^{\circ}=1$ dalam interval $-\pi<x<\pi$ !

b. Periksa kebenaran jawaban point a dengan menyelesaikan persamaan trigonometri tersebut!

Setelah diberikan soal tes berpikir kritis, untuk mendapatkan data yang lebih mendalam maka dilakukan wawancara. Data yang telah diperoleh kemudian dianalisis dan dipaparkan dalam bentuk deskripsi berdasarkan aspek berpikir kritis FRISCO. Berikut uraian profil kemampuan berpikir kritis matematis S1 dan S2:

Profil Kemampuan Berpikir Kritis Matematis S1.

Pada tahap awal, langkah yang dilakukan oleh S1 untuk menyelesaikan soal adalah dengan membaca soal terlebih dahulu.
Setelah membaca, S1 mampu menjelaskan yang ditanyakan dan menyebutkan informasi pada soal. Hal ini dapat dilihat dari pernyataan subjek: "Nomor satu yang ditanyakan adalah nilai $x$ yang memenuhi persamaan $\quad \sin (2 x-30)^{\circ}=1$. Kita diminta untuk menyelesaikan soal ini dengan sketsa grafik, ini untuk yang 1 , dalam suatu interval $-\pi<x<\pi$, yang $\mathrm{b}$ membuktikan dengan perhitungan". Hal ini menunjukkan ada aspek berpikir kritis focus dari S1.

S1 juga dapat memberi penjelasan akan istilah-istilah dalam soal. S1 mengatakan: "Sketsa grafik itu suatu perkiraan saja dan ada skalanya, kalau grafik ukuranya lebih presisi atau sesuatu yang mutlak", sedangkan interval adalah: "...rentang dalam hal yang lebih umumnya, atau selang sebagai bataslah", dan persamaan adalah: "Dua nilai yang salah satu atau keduanya memuat variabel yang bernilai sama, kedua nilai itu punya harga yang setara". Berdasarkan jawaban tersebut tampak bahwa S1 memenuhi aspek clarity dikarenakan S1 mampu mengklarifikasi dan menjelaskan semua istilah yang diperoleh dari soal.

Sesuai soal, maka langkah pertama yang dilakukan S1 adalah mengerjakan soal a (membuat sketsa grafik). Dalam membuat sketsa grafik, S1 pertama kali menentukan nilai-nilai $x$ yang akan menjadi titik acuan dengan syarat jika disubstitusikan pada $\sin \left(2 x-30^{\circ}\right)$ maka dapat diperoleh sudut-sudut istimewa. Contohnya, memilih $x=15^{\circ}$ sehingga jika disubstitusikan ke $\sin \left(2 x-30^{\circ}\right)$ menghasilkan nol. Demikian juga untuk selanjutnya, karena titik nol didapat pada sudut $15^{\circ}$ maka seterusnya 
nilai $x$ yang digunakan merupakan

kelipatan dari $15^{\circ}$ dengan batas sesuai interval pada soal.

Berdasarkan hal tersebut, maka dapat dikatakan pada langkah ini S1 menunjukkan aspek reason. Jawaban S1 soal a dapat dilihat pada Gambar 1:

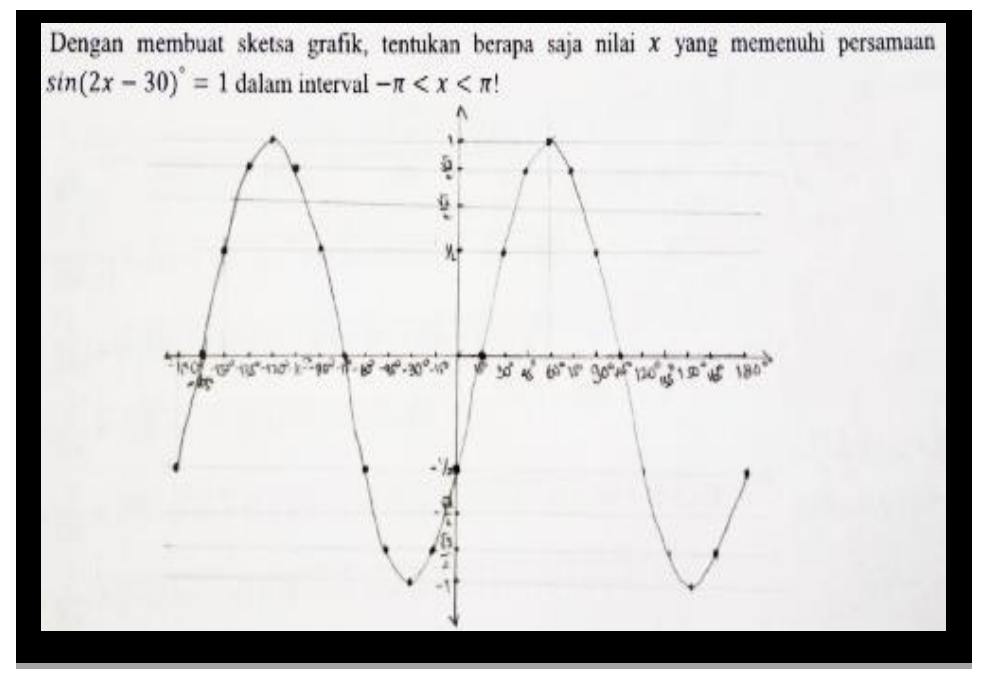

Gambar 1. Jawaban S1 Soal a

Keberhasilan dalam menyelesaikan soal a dikarenakan juga S1 memenuhi aspek situation, dimana S1 memiliki pengetahuan tentang menggambar grafik dengan menentukan pasangan ordinat dan absis.

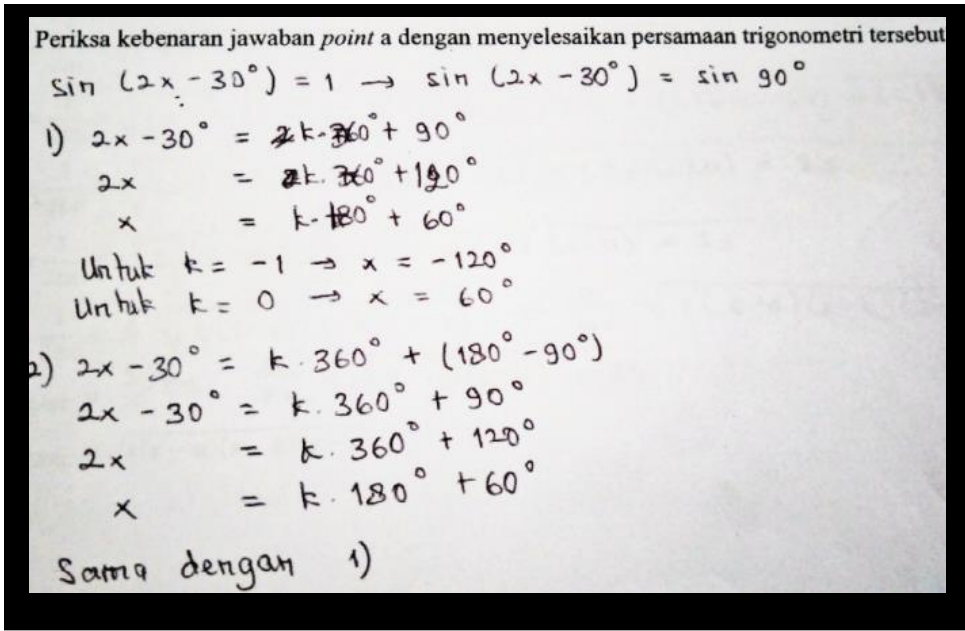

Gambar 2. Jawaban S1 Soal b

Pada soal b, S1 mencari sudut agar nilai sinnya sama dengan satu. Hal ini bertujuan untuk membawa kedua ruas kedalam bentuk persamaan $\sin x=\sin \alpha$ dengan $x=k \cdot 360^{\circ}+\alpha$. Meski demikian, S1 tidak mengetahui alasan penggunaan rumus tersebut. S1 menyatakan bahwa: "Seperti yang diajarkan diperkuliahan, dicari nilai $\sin (2 x-30)^{\circ}$ kan sama dengan 1 , sedangkan fungsi sinus yang nilainya 1 itu saat nilai $x$ nya $90^{\circ}$, berarti nanti kita dapat $\sin (2 x-30)^{\circ}=\sin 90^{\circ} \quad$ setelah itu 
diselesaikan seperti biasa". Hal ini menunjukkan bahwa aspek reason yang ditunjukkan S1 hanya untuk membawa soal dalam bentuk $\sin x=\sin \alpha$, namun $\mathrm{S} 1$ tidak mampu menunjukkan aspek reason dalam memilih persamaan $x=k \cdot 360^{\circ}+$ $\alpha$. Langkah tersebut diambil karena S1 pernah menyelesaikan soal serupa, sehingga pada langkah ini menunjukkan adanya aspek situation. Tidak hanya mencari nilai $x$, S1 juga melakukan pemeriksaan terhadap nilai-nilai $x$ apakah memenuhi interval atau tidak. Hal ini menunjukkan bahwa sampai pada tahap ini S1 masih focus dengan informasi pada soal.

Ketika memperoleh jawaban di soal $b$, S1 menyatakan bahwa: "Setelah dapat polanya tidak dicek lagi, karena kan jawabannya konsisten, kemungkinan dua hal yang konsisten tapi sama-sama salah itu kan kecil", dari pernyataan tersebut tampak adanya aspek overview. S1 melihat langkah dari penyelesaian yang telah dibuat, saat dirasa tidak ada langkah yang salah maka S1 menyimpulkan bahwa jawaban yang diperoleh benar. Hal tersebut menunjukkan bahwa pada tahap ini aspek inference muncul dari S1. Pada tahap terakhir S1 membandingkan nilai $x$ hasil perhitungan dengan nilai $x$ yang diperoleh dari sketsa grafik. Hal ini kembali menunjukkan bagaimana memperlihatkan aspek focus dilangkahlangkah terakhir (langkah dimana S1 telah memperoleh jawaban).

Profil Kemampuan Berpikir Kritis Matematis S2.

Pada tahap awal, langkah yang dilakukan oleh S2 untuk menyelesaikan soal adalah dengan membaca soal terlebih dahulu. Setelah membaca, S2 mampu menjelaskan yang ditanyakan dan menyebutkan informasi pada soal. Hal ini dapat dilihat dari pernyataan subjek: "Membuat grafik dan menentukan nilai $x$ yang memenuhi persamaan dan diketahui intervalnya untuk menentukan nilai $x$ nya". Hal ini menunjukkan ada aspek berpikir kritis focus dari S2.

S2 juga dapat memberi penjelasan akan istilah-istilah dalam soal. S2 menyatakan bahwa yang dimaksud interval adalah: "Batas yang digunakan untuk mencari nilai $x$ ", sedangkan persamaan adalah: "Kedua ruas punya nilai sama, yang ada tanda sama dengannya", dan sketsa grafik adalah: "Mungkin gambar grafik dari persamaan ini untuk mencari nilai $x$ nya". Sampai pada tahap ini dapat dikatakan bahwa S2 dapat menunjukkan aspek clarity karena S2 mampu mengklarifikasi dan menjelaskan istilah yang diperoleh dari soal, namun S2 sebenarnya tidak memahami arti dari istilah-istilah yang diperoleh. Hal ini dapat dilihat pada kutipan wawancara berikut:

P : Beda nggak sketsa grafik sama grafik?

S2 : Beda

$\mathrm{P} \quad$ : Lalu apa bedanya?

S2 : Emm gimana ya

Berdasarkan pernyataan tersebut, ketika ditanya mengenai perbedaan antara grafik dan sketsa grafik S2 merasa bingung.

S2 tidak dapat menyelesaikan soal a dan pada jawaban tertulis hanya menggambar sumbu $x$ dan sumbu $y$, jawaban tertulis $\mathrm{S} 2$ pada soal a dapat dilihat pada Gambar 3. 


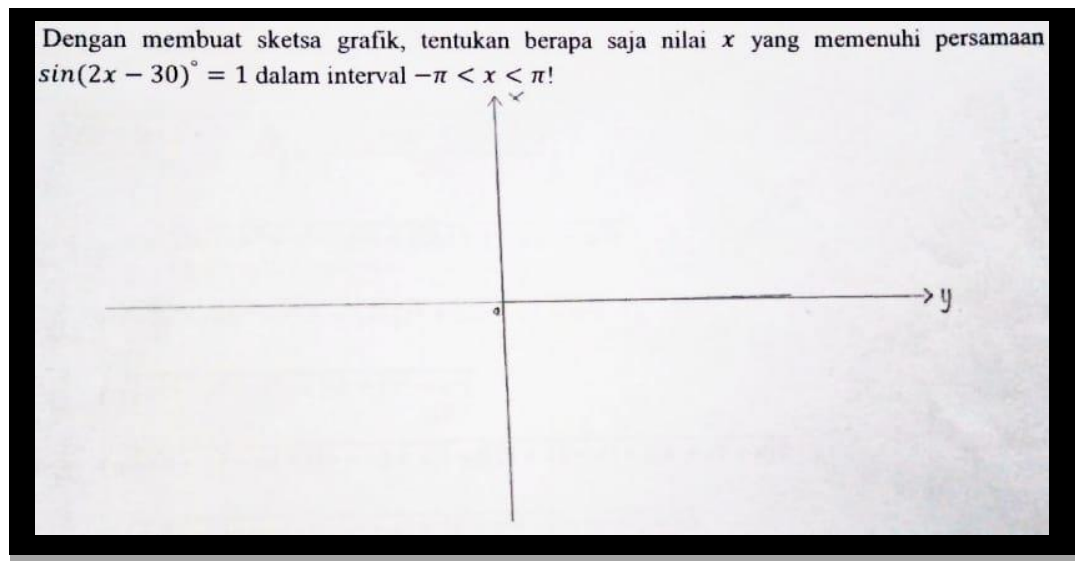

Gambar 3. Jawaban S2 soal a

S2 menyatakan bahwa dia tidak titik acuan untuk membuat grafiknya. menyelesaikan sketsa grafik tersebut dikarenakan bingung dalam menentukan nilai $x$ sehingga tidak dapat menentukan titik acuan untuk menggambar grafik. Hal ini dapat dilihat pada kutipan wawancara berikut: "Karena saya bingung menentukan nilai $x$ dan titik acuan buat nggambar grafiknya". Berdasarkan pernyataan tersebut dapat disimpulkan bahwa menurut S2 untuk membuat grafik harus mengetahui nilai $x$ sehingga mengetahui Ketika diwawancarai S2 juga menyatakan bahwa dia hafal grafik dari $\sin x$ dan mampu menggambarkannya, tetapi bingung jika diminta untuk membuat grafik $\sin (2 x-30)^{\circ}$. Oleh karena itu dapat dikatakan bahwa S2 memiliki konsep untuk membuat grafik, tetapi tidak dapat menerapkan konsep tersebut kedalam situasi yang lain sehingga pada tahap ini dapat dikatakan bahwa S2 tidak mampu memperlihatkan aspek situation.

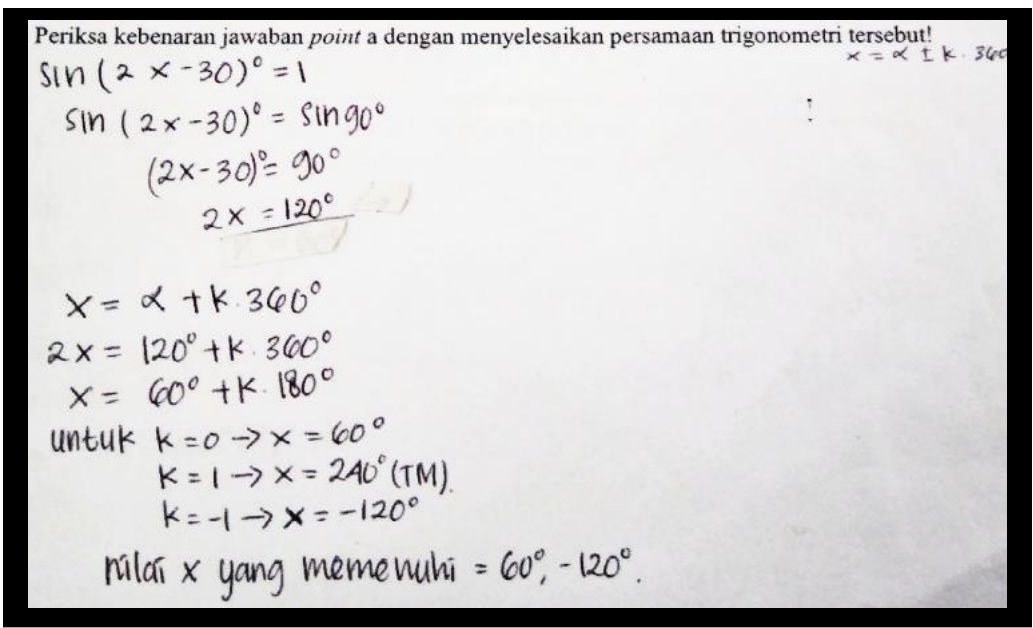

Gambar 4. Jawaban S2 Soal b

Pada soal b, S2 mampu memberi alasan dari beberapa langkah yang dilakukan di soal b. Contohnya, S2 menyatakan bahwa penggantian nilai 1 dengan $\sin 90^{\circ}$ dikarenakan $\sin 90^{\circ}$ bernilai 1 dan mengapa memilih perbandingan trigonometri sin dikarenakan menyamakan dengan ruas kiri yang sudah memuat $\sin$. 
Berikut penjelasan S2 akan hal ini: "Ini kan ada nilai 1 lalu agar sama seperti ruas kiri kita ganti nilai 1 dengan sin yang bernilai 1". Selain itu S2 juga mampu memberikan prinsip mengenai pengecekan nilai $x$ yang memenuhi atau tidak dengan menggunakan rumus $x=\propto+k .360^{\circ}$. S2 menyatakan bahwa menggunakan rumus tersebut dikarenakan hafal dengan rumus tersebut dan pernah mendapatkannya pada proses perkuliahan. Hal ini menunjukkan bahwa aspek reason yang ditunjukkan oleh S2 hanya untuk membawa kedua ruas kedalam bentuk $\sin x=\sin \alpha$, namun S2 tidak mampu menunjukkan aspek reason dalam memilih persamaan $x=k \cdot 360^{\circ}+\alpha$. Langkah tersebut diambil karena S2 pernah menyelesaikan soal serupa, sehingga pada langkah ini menunjukkan adanya aspek situation. Tidak hanya mencari nilai $x$, S2 juga melakukan pemeriksaan terhadap nilai-nilai $x$ apakah memenuhi interval atau tidak. Hal ini menunjukkan bahwa sampai pada tahap ini S2 masih fokusdengan informasi pada soal.

Ketika mampu memperoleh jawaban dari soal b, S2 menyimpulkan bahwa soal a pasti memiliki penyelesaian, walaupun pada kenyataannya S2 tidak dapat menyelesaikan soal a. Hal ini dapat dilihat pada kutipan wawancara berikut:

$P$ : Kamu tau nggak kalau nanti dari grafik itu pasti ada solusinya yang memenuhi persamaan $\sin (2 x-$ $30)^{\circ}=1$ ?

S2 : Tau, pasti ada

Selain itu, S2 juga menyimpulkan bahwa jawaban yang didapat pada soal b sudah pasti benar dan tidak ada lagi jawaban yang lain. Hal ini dikarenakan dalam melakukan perhitungan, ketika mensubstitusi $k$ yang nilainya lebih dari 1 ke dalam rumus $x=$ $60^{\circ}+k \cdot 180^{\circ}$ maka hasilnya tidak memenuhi interval yang diminta oleh soal. Berikut kutipan wawancara yang menunjukkan hal tersebut:

$P$ : Berarti bener ya? Kamu yakin $-120^{\circ}$ sama $60^{\circ}$ jawaban yang benar?

S2 : lya yakin

$\mathrm{P}$ : Apakah ada jawaban lain?

S2 : Enggak ada

Dari kesimpulan-kesimpulan yang telah dibuat, tampak bahwa pada tahap ini S2 menunjukkan aspek inference.

Setelah selesai mengerjakan S2 tidak melakukan pemeriksaan kembali terhadap jawabannya. Hal ini dikarenakan dugaan awal S2 ketika tidak dapat membuat grafik pada soal a maka tidak dapat melakukan pemeriksaan jawaban terhadap soal b. S2 juga menyatakan bahwa sudah bingung terlebih dahulu karena tidak bisa membuat sketsa grafik sehingga tidak berupaya lagi untuk memanfaatkan jawaban yang diperoleh pada soal b untuk membuat sketsa grafik. Berikut kutipan wawancara akan hal ini:

P : Ini kan kamu sudah dapat 2 jawaban, kamu nggak coba gunakan jawabanmu untuk ngecek di soal a, mungkin dengan cara apa gitu?

S2 : Enggak mas, karena sudah bingung dulu cara buat grafiknya

Hal ini menunjukkan bahwa sampai pada tahap akhir S2 tidak mampu memperlihatkan aspek overview.

Berdasarkan hasil penelitian yang diperoleh, pada tahap focus baik S1 maupun S2 mampu mengidentifikasi informasi yang ada dan mampu menyatakan tujuan dari soal yang 
diberikan. Pada tahap reason, S1 mampu memberikan alasan terhadap setiap langkah penyelesaian yang diambil secara rinci berbeda dengan S2 yang dalam memberikan alasan secara singkat. Pada tahap inference, S1 membuat kesimpulan mengenai kebenaran jawaban dengan dua cara yaitu dengan melihat kekonsistenan langkah dan jawaban pada soal a dan b sedangkan S2 hanya membuat kesimpulan mengenai kebenaran jawaban dengan melihat kekonsistenan langkah. Pada tahap situation, S1 memiliki pengetahuan yang mendalam mengenai konsep dalam menggambar grafik sin serta perhitungan trigonometri. Berbeda dengan S2 yang memiliki pengetahuan maupun konsep trigonometri yang terbatas dan lebih mengandalkan hafalan sehingga berdampak pada saat diberi situasi permasalahan yang berbeda tidak dapat menyelesaikannya. Pada tahap clarity, S1 mengetahui dan mampu mengklarifikasi serta memahami istilah-istilah yang digunakan. Begitu pula dengan S2, tetapi dalam mengklarifikasi istilah-istilah tersebut terlihat pemahaman S2 tidak terlalu mendalam dan juga lebih mengandalkan hafalan. Pada tahap overview, S1 memeriksa kebenaran jawaban dengan cara melihat setiap langkah penyelesaian yang diambil sudah sesuai serta melihat kekonsistenan jawaban yang diperoleh pada soal a dan $b$. Berbeda dengan S2 yang tidak melakukan pemeriksaan terhadap jawabannya karena soal a tidak terselesaikan sehingga kekonsistenan jawaban tidak terlihat, selain itu S2 juga tidak mencari cara lain untuk memeriksa jawaban yang diperoleh. Hal ini menunjukkan bahwa kurangnya kepercayaan diri pada S2 yang membuatnya berhenti untuk tidak mencari jalan keluar lain. Sejalan dengan hal ini, Lauster(1997)menyatakan bahwa seseorang yang percaya diri selalu berusaha mencari jalan keluar untuk menghadapi masalah-masalah yang sedang dihadapinya. Uraian profil berpikir kritis tersebut sejalan dengan pendapat Hendriana dkk., (2017) yang mengemukakan bahwa dalam berpikir kritis segala kemampuan diberdayakan, baik itu memahami, mengingat, membedakan, menganalisis, memberi alasan, merefleksikan, menafsirkan, mencari hubungan, mengevaluasi, bahkan membuat dugaan sementara.

\section{Penutup}

Berdasarkan hasil analisis dan pembahasan yang telah dilakukan dapat disimpulkan bahwa perbedaan kepercayaan diri juga berdampak pada kemampuan berpikir kritis mahasiswa. S1 yang merupakan subjek dengan kepercayaan diri tinggi mampu menyelesaikan soal dengan benar dan mampu memenuhi semua aspek FRISCO. Pada tahap focus, S1 mampu mengidentifikasi informasi dan menyatakan tujuan dari soal yang diberikan. Pada tahap reason, S1 mampu memberikan alasan terhadap setiap langkah penyelesaian yang diambil secara rinci. Pada tahap inference, S1 membuat kesimpulan mengenai kebenaran jawaban dengan dua cara yaitu dengan melihat kekonsistenan langkah dan jawaban pada soal a dan b. Pada tahap situation, S1 memiliki pengetahuan yang mendalam mengenai konsep dalam menggambar grafik serta perhitungan 
trigonometri. Pada tahap clarity, S1 mengetahui, mampu menjelaskan secara rincidan memahami istilah-istilah yang digunakan. Pada tahap overview, S1 memeriksa kebenaran jawaban dengan cara melihat setiap langkah penyelesaian yang diambil sudah sesuai serta melihat kekonsistenan jawaban yang diperoleh pada soal a dan b.

S2 yang merupakan subjek dengan kepercayaan diri rendah tidak mampu menyelesaikan soal yang diberikan dan hanya memenuhi aspek focus, reason, inferencedan clarity. Pada tahap focus, S2 mampu mengidentifikasi informasi dan mengetahui tujuan dari soal yang diberikan. Pada tahap reason, S2 mampu memberikan alasan terhadap penyelesaian yang diambil tetapi tidak semua langkah bisa dijelaskan karena jawaban soal a tidak terselesaikan. Pada tahap inference, S2 membuat kesimpulan mengenai kebenaran jawaban dengan melihat kebenaran langkah penyelesaian yang diambil. Pada tahap situation, pengetahuan maupun konsep yang dimiliki S2 dalam trigonometri terbatas dan lebih mengandalkan hafalan sehingga berdampak ketika diberi situasi permasalahan yang berbeda tidak dapat menyelesaikannya. Pada tahap clarity, S2 mampu menyebutkan dan menjelaskan istilah-istilah yang ada. Pada tahap overview, S2 tidak melakukan pemeriksaan terhadap jawabannya karena soal a tidak terselesaikan sehingga kekonsistenan jawaban tidak terlihat, selain itu S2 juga tidak mencari cara lain untuk memeriksa jawaban yang diperoleh.

\section{DAFTAR PUSTAKa}

Alexandra, G., \& Ratu, N. (2018). Profil
Kemampuan Berpikir Kritis Matematis Siswa Smp dengan Graded Response Models. Mosharafa: Jurnal Pendidikan Matematika, 7(1), 104.

Depdikbud. (2017). Modul Penyusunan Soal High Order Thinking Skill (HOTS). Jakarta: Depdikbud.

Ennis, R. H. (1996). Critical Thinking Dispositions: Their Nature and Assessability. Informal Logic, 18(1996), 165-182.

https://doi.org/10.1353/jge.2007.001 1

Fasikhah, S. S. (1994). Peranan kompetensi sosial pada tingkah laku koping remaja akhir. Universitas Gajah Mada. https://doi.org/10.23917/indigenous.v $2 \mathrm{i} 2.4748$

Gunawan, A. W. (2013). Genius learning strategi: Petunjuk prakti suntuk menerapkan accelerated learning. Jakarta: Gramedia Pustaka Utama.

Hendriana, H. (2014). Membangun Kepercayaan Diri Siswa Melalui Pembelajaran Matematika Humanis. Jurnal Pengajaran MIPA, 19(1), 56. https://doi.org/http://dx.doi.org/10.1 8269/jpmipa.v19i1.424

Hendriana, H., Rohaeti, E. E., \& Sumarmo, U. (2017). Hard Skills dan Soft Skills Matematika Siswa. Bandung: Refika Aditama.

Heong, Y. M., Othman, W. B., Yunos, J. B. M., Kiong, T. T., Hassan, R. Bin, \& Mohamad, M. M. B. (2011). The Level of Marzano Higher Order Thinking Skills among Technical Education Students. International Journal of Social Science and Humanity, 1(2), 121.

https://doi.org/10.7763/IJSSH.2011.V 
1.20

King, F., Ludwika, G., \& Rohani, F. (2009). Higher Order Thinking Skills. Retrieved from

http://www.cala.fsu.edu/files/higher_ order_thinking_skills.pdf

Lauster, P. (1997). Tes Kepribadian (terjemahan Cecilia, G. Sumekto). Yogyakarta: Kanisius.

Mahardiningrum, A. S., \& Ratu, N. (2018). Profil Pemecahan Masalah Matematika Siswa Smp Pangudi Luhur Salatiga Ditinjau dari Berpikir Kritis. Mosharafa: Jurnal Pendidikan Matematika, 7(1), 77.

Paradesa, R. (2015). Kemampuan Berpikir

Kritis Matematis Mahasiswa Melalui Pendekatan Konstruktivisme pada Matakuliah Matematika Keuangan. Jurnal Pendidikan Matematika JPM RAFA, 1(2), 324-325.

Razak, F. (2017). Hubungan Kemampuan Awal Terhadap Kemampuan Berpikir Kritis Matematika Pada Siswa Kelas Vii Smp Pesantren Immim Putri Minasatene. Mosharafa: Jurnal Pendidikan Matematika, 6(1), 121. https://doi.org/10.1017/S1041610213 000598

Santoso, F. G. I. (2016). Kemampuan berpikir kritis mahasiswa dalam menyelesaikan soal analisis melalui pembelajaran matematika berdasarkan masalah. Jurnal Edukasi Matematika Dan Sains, 1(1), 11.

Tresnawati, Hidayat, W., \& Rohaeti, E. E. (2017). Kemampuan Berpikir Kritis Matematis dan Kepercayaan Diri Siswa SMA. Pasundan Journal of Research in Mathematics Learning and Education, 2(2), 42.
Zetriuslita, Ariawan, R., \& Nufus, H. (2016). Analisis Kemampuan Berpikir Kritis Matematis Mahasiswa Dalam Menyelesaikan Soal Uraian Kalkulus Integral Berdasarkan Level Kemampuan Mahasiswa. Infinity Journal, 5(1), 64. https://doi.org/10.22460/infinity.v5i1. 193

\section{Riwayat Hidup Penulis}

\section{Bagus Dwi Wicaksono, S.Pd.}

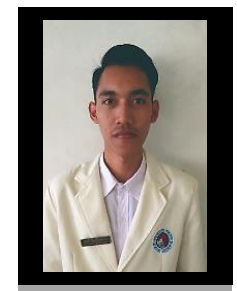

Lahir di Salatiga, 22 Maret 1997. Studi S1 Pendidikan Matematika Universitas Kristen Satya Wacana, Salatiga.

\section{Erlina Prihatnani, S.Si. M.Pd.}

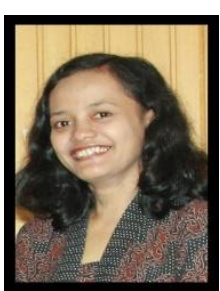

Lahir di Purworejo, 10 Agustus 1984. Dosen Program Studi Pendidikan Matematika Universitas Kristen Satya Wacana, Salatiga. S1 Matematika FSM Universitas Kristen Satya Wacana Salatiga, S2 Pendidikan Matematika Universitas Sebelas Maret Surakarta. 